\title{
WHEN SHOULD PRECAUTION PREVAIL? INTERESTS IN (PUBLIC) HEALTH, THE RISK OF HARM AND XENOTRANSPLANTATION
}

\author{
SARA FOVARGUE AND SUZANNE OST*
}

\section{INTRODUCTION}

Xenotransplantation highlights conflicting interests in the health of the public between a specific interest in enhancing the health of those individuals who require a (xeno)transplant, and a wider interest in protecting the health of us all by avoiding infectious diseases which may be transmitted across the species barrier and then to others following such a procedure. There is also a third type of public interest which comes into play here - the interest in advancing medical knowledge and treatment. Given the significant shortage of organs for transplantation, ${ }^{1}$ the continued development of xenotransplantation could be a means of addressing the shortfall and thereby serving all three interests. Interest in the health of individuals is at the heart of all health care systems and, in some countries, has been used to support, not always successfully, ideas of individual rights to particular health care treatments, or procedures and individual autonomy regarding health. ${ }^{2}$ Whilst the precedence given to individual rights and autonomy has been questioned judicially, and in legal and bioethical literature, ${ }^{3}$ bioethics frameworks do not tend to tackle public health dilemmas and the conflicts that arise when some individuals behave in a way that affects others. ${ }^{4}$ This

\footnotetext{
* Law School, Lancaster University. A version of this paper was presented to a Lancaster University Centre for Bioethics and Medical Law seminar on Exploring Health Care Law's Recognition of Autonomy and Rights held in March 2009. We are grateful to participants for their comments and the insightful debate which followed. Thanks also to the anonymous reviewers and to José Miola and Hazel Biggs for their comments.

${ }^{1}$ For statistics from 1 April 2008-31 March 2009 see http://www.uktransplant.org.uk/ukt/statistics/statistics.jsp.

${ }^{2}$ See, for example, $R$ (on the application of Purdy) v DPP [2009] UKHL 45; $R$ (on the application of Burke) $v$ $G M C$ [2005] EWCA Civ 1003; $R$ v Cambridge DHA, ex p $B$ [1995] 2 All ER 129.

${ }^{3}$ For example, $R v$ Collins and another, ex parte Brady (2000) 58 BMLR 173; J Coggon, 'Varied and Principled Understandings of Autonomy in English Law: Justifiable Inconsistency or Blinkered Moralism?' (2007) 15 Health Care Analysis 235.

${ }^{4}$ Nuffield Council on Bioethics, Public Health: Ethical Issues (2007) Nuffield Council on Bioethics, 145 and xvi. For criticisms of this report see J Coggon, 'Harmful Rights-Doing? The Perceived Problem of Liberal Paradigms and Public Health' (2008) 34 Journal of Medical Ethics 798.
} 
paper explores how matters of private benefit and public risk can be appropriately reconciled in the context of xenotransplantation. ${ }^{5}$

Others have noted the tensions raised by xenotransplantation; ${ }^{6}$ however, much of the debate concedes that risks to xeno-recipients and others may exist but then focuses on managing those harms. ${ }^{7}$ We take a step back and explore whether ideas of public health need to take a central role when answering the question of whether clinical xenotransplantation should proceed. In doing so, we consider whether priority should be afforded to the private and public interest in the possible benefit to the individual who requires a xenotransplant, or to the risk of harm to all of us caused by introducing a new human pathogen into the community. We explore whether the public interest requires that preventative measures are taken in advance because xenotransplantation poses a threat to public health, and argue that the interests of the individual requiring a xenotransplant must be weighed with more collectivist concerns for public health. In this we are persuaded by the argument that proportionality is more appropriate in risk contexts, and more respectful of human rights. ${ }^{8}$ This is of particular note for xenotransplantation given the surveillance and monitoring regimes xeno-recipients, and others, are likely to be asked to adhere to. ${ }^{9}$

Whilst we are primarily concerned with the first two interests noted above, the health of individuals and public health, it is axiomatic to say that there is also an interest in the advancement of science and medicine, for many of us and those we love and care for may not

\footnotetext{
${ }^{5}$ To use terminology employed by RE Gold, WA Adams, 'Reconciling Private Benefit and Public Risk in Biotechnology: Xenotransplantation as a Case Study in Consent' (2002) 10 Health Law Journal 31, 32.

${ }^{6}$ For example, SAM McLean, L Williamson, Xenotransplantation: Law and Ethics (2005) Ashgate, 179-185.

${ }^{7}$ Discussed in, for example, A Ravelingien, 'Xenotransplantation and the Harm Principle: Factoring Out Foreseen Risk' (2007) 16 Journal of Evolution and Technology 127.

${ }^{8}$ T Murphy, N Whitty, 'Is Human Rights Prepared? Risk, Rights and Public Health Emergencies' (2009) 17 Medical Law Review 219, 236.

${ }^{9}$ See (n 39-45) and accompanying text.
} 
be here today without the development of what are now seen as mundane drugs, treatments or procedures, such as antibiotics, chemotherapy or organ transplants. At one point in their development, a decision was made to clinically proceed with these advances because, presumably, the benefit which could be attained if successful would exceed any side-effects or risks. There is the "technological imperative", ${ }^{10}$ the drive to continue to develop drugs, procedures, treatments and techniques and, for some, the "seductive sirens of medical progress" may be hard to ignore. ${ }^{11}$ At the same time such progress needs to take account of a wider perspective - just because something can technically be done does not necessarily or automatically mean that it should be. Indeed, some proposed medical advances may pose too great a risk to the potential recipient and others, raising questions as to whether they should be clinically introduced. However, the reality and implications of adopting this position may make it harder to implement. Who wants to be the one to tell those on the transplant waiting list that research on the developing biotechnology they have seen reported in the press has been halted because there might be risks to others? Despite these difficult discussions, we support Sommerville's argument that:

... the new science has moved us from chance to choice in many matters ... With choice comes the responsibility to use that choice ethically. Doing so requires two kinds of courage: the courage to go forward with the new science and technology when it is morally and ethically acceptable to do so, and the courage to exercise restraint when it is morally and ethically required. ${ }^{12}$

\footnotetext{
${ }^{10}$ I Kennedy, Treat Me Right - Essays in Medical Law and Ethics (1988) Clarendon Press, 288.

${ }^{11}$ MJ Hanson, 'The Seductive Sirens of Medical Progress - The Case of Xenotransplantation' (1995) Hastings Center Report 5.

12 MA Sommerville, 'Searching for Ethics in a Secular Society' in Ethics of Science and Technology, Explorations of the Frontiers of Science and Ethics (2006) UNESCO, 29: http://unesdoc.unesco.org/images/0014/001454/145409e.pdf.
} 
It is at this point that an interest in the health of the public and an interest in the health of the individual may conflict, with this tension exacerbated by the interest in advancing medicine which may benefit all or any one of us.

The concept of risk is central to our analysis given that the consequences of xenotransplantation are events of the future; it is a biotechnology that threatens and promises potential future harm as well as possible benefit. There is much critical literature on risk, the logic of risk and the repercussions of a focus on risk in contemporary society. ${ }^{13} \mathrm{~A}$ widespread fear of risk has arguably made it easier to rely on knowledge of the possible risks a phenomenon poses to justify preventative (legal) action to forestall harm. ${ }^{14}$ Yet when it comes to the question of whether to utilise a biotechnology that may have a significant impact on individuals and society, risks of harm cannot and should not be ignored. We do not pretend that the risks posed by xenotransplantation are certain, but the nature of the harm to public health that this biotechnology could unleash is severe. We argue that it is sometimes legally and ethically necessary for the state to act to protect the health of the public, and that xenotransplantation is a case in point. Some have suggested that because of the risk of possible harm, the public should be consulted about using xenotransplantation and/or that the non-human animals, the xeno-recipients and, possibly, others should be subject to surveillance and monitoring schemes pre- and post-xenotransplant. However, we go further. ${ }^{15}$ Because of the limited evidence that xenotransplants will be a viable solution to the organ shortage problem (benefit), and the extreme risks of harm that accompany this

\footnotetext{
${ }^{13}$ See for example, A Giddens, Consequences of Modernity (1990) Polity; U Beck, Risk Society: Towards A New Modernity (1992) Sage Publications; B Hudson, Justice in the Risk Society: Challenging and Reaffirming 'Justice' in Late Modernity_(2003) Sage; G Mythen, S Walklate (eds), Beyond the Risk Society: Critical Reflections on Risk and Human Security (2006) Open University Press; U Beck, World at Risk (2009) Polity.

${ }^{14}$ In the context of criminal law, see, for example, S Ost, Child Pornography and Sexual Grooming: Legal and Societal Responses (2009) Cambridge University Press.

${ }^{15}$ See, for example, C Smetanka, DKC Cooper, 'The Ethics Debate in Relation to Xenotransplantation' (2005) 24 Revue Scientifique et Technique Office International des Épizooties 335; United Kingdom Xenotransplantation Interim Regulatory Authority (UKXIRA), Draft Report of the Infection Surveillance Steering Group of the UKXIRA (1999) Department of Health (DH).
} 
biotechnology, it should not proceed to clinical trials. Our conclusion is supported by our modification of the precautionary principle with Mill's harm principle to aid us in determining how the tension in the different notions of public health can be addressed.

Our paper is split into seven sections. We first set out the risks of xenotransplantation, results of pre-clinical and clinical trials, and how it is regulated in the UK. We then outline the model of risk we have adopted, before discussing how interests in the health of the public and in public health are called into play by this developing biotechnology. In the final three sections we explore and then apply our two key principles (precautionary and harm) to the risks of xenotransplantation.

\section{XENOTRANSPLANTATION}

In the UK, xenotransplantation is defined as:

... any procedure that involves the transplantation, implantation, or infusion into a human recipient of either live tissues or organs retrieved from animals, or, human body fluids, cells, tissues or organs that have undergone ex vivo contact with live nonhuman animal cells, tissues or organs. ${ }^{16}$

This biotechnology has been developed because of the shortfall in the number of human organs available for transplantation worldwide. It is hoped that if a xenotransplant proves able to support human life, then a consistent supply of pig organs, cells and tissues can be genetically engineered for transplantation in to humans. Research into cellular xenotransplantation is also proceeding. Our focus is on solid organ xenotransplantation as no

\footnotetext{
${ }^{16}$ DH, Xenotransplantation Guidance (2006), 1: http://www.advisorybodies.doh.gov.uk/ukxira. This replicates the definition set out in Directive 2003/63/EC amending Directive 2001/83/EC of the European Parliament and of the Council on the Community code relating to medicinal products for human use, at Annex I, Part IV.
} 
such genetically engineered organ has yet been xenotransplanted from a pig to a human. For this to occur three main scientific barriers must be overcome, immunological, physiological and microbiological and it is the latter which is of concern to us here. ${ }^{17}$

\section{A. Microbiological barriers to xenotransplantation - the risk}

The immunological and physiological barriers to xenotransplantation focus on the pig or the human xeno-recipient individually, and whilst there is a risk of transmitting infectious diseases following an allotransplant, these are predominantly limited to the individual organ recipient. ${ }^{18}$ In contrast, the microbiological barriers to xenotransplantation may go further as there is an inherent risk of transmitting infectious diseases from the pig to the xeno-recipient and, possibly, on to her close contacts and the wider public. The problem is that 'when one tests animal-to-human transplants, one is also carrying out another, unwanted, experiment testing the remote but real danger that animal viruses might jump to humans and cause manmade pandemics' 19

There are two main types of infectious diseases which may be transmitted to the xenorecipient and possibly others - known and unknown diseases. During the 1990s it was discovered that porcine endogenous retroviruses (PERVs) could infect human cells in vitro and, under certain circumstances, actively infect human cells, meaning they can replicate and spread to other cells in the patient. As such, they have been the focus of concern. PERVs are present in multiple copies in every pig genome, have been linked to cancers of the blood,

\footnotetext{
${ }^{17}$ For further information on the first two barriers see, for example, B Petersen, JW Carnwath, H Niemann, 'The Perspectives for Porcine-to-Human Xenografts' (2009) 32 Comparative Immunology, Microbiology and Infectious Diseases 91; S Le Bas-Bernardet, G Blancho, 'Current Cellular Immunological Hurdles in Pig-to Primate Xenotransplantation' (2009) 21 Transplant Immunology 60; JM Dobson, JH Dark, The Physiology of Xenotransplantation (2002) DH, Ch. 1.

${ }^{18}$ See, for example, DA Muir, G Griffin, Infection Risks in Xenotransplantation (2001) DH, 8.

${ }^{19}$ D Butler, 'Last Chance to Stop and Think on Risks of Xenotransplants' (1998) 391 Nature 320, 320.
} 
conditions involving an impaired immune system, and neurodegenerative disorders. ${ }^{20}$ Retroviruses are dangerous because although they may be harmless in the host non-human animal they are potentially lethal once transferred cross-species. HIV is a retrovirus. PERVs are also capable of recombination with viruses from the host species, raising fears that such recombination could 'generate viruses with novel mechanisms of virulence'. ${ }^{21}$ And '[e]vidence from naturally occurring retroviral zoonosis and cross-species infections by animal retroviruses, for example, HIV, provides a basis for reasoned speculation on the risk posed by PERVs. In a worst case scenario xenograft-related PERV transmission would be the starting point of a new viral disease resulting in a public health problem' ${ }^{22}$

The dangers of PERVs may be difficult to categorise definitively, but experiences with other retroviruses indicate they are unlikely to be responsible for flu-like symptoms; rather, a higher order of fluid-borne infectious disease affecting the immune system or blood is anticipated. The consequences of PERVs are also hard to identify but we can reasonably speculate that, given our experiences with HIV, xenotransplantation may introduce a lethal infectious disease pandemic. It is unclear whether PERVs represent a small risk to many or a high risk to a few, but it is clear that 'the risk of PERV infection following [xenotransplantation] will never be zero. ${ }^{23}$

\footnotetext{
${ }^{20} \mathrm{~V}$ Specke and others, 'No In Vivo Infection of Triple Immunosuppressed Non-Human Primates after Inoculation with High Titers of Porcine Endogenous Retrovirus' (2009) 16 Xenotransplantation 34; G Mattiuzzo, L Scobie, Y Takeuchi, 'Strategies to Enhance the Safety Profile of Xenotransplantation: Minimimizing the Risk of Viral Zoonoses' (2008) 13 Current Opinion in Organ Transplantation 184.

${ }^{21}$ C Moran, 'Xenotransplantation: Benefits, Risks and Relevance of Reproductive Technology' (2008) Theriogenology 1269, 1271.

${ }^{22}$ D Louz and others, 'Reappraisal of Biosafety Risks Posed by PERVs in Xenotransplantation' (2008) 18 Reviews in Medical Virology 53, 60.

${ }^{23}$ C Patience, L Scobie, G Quinn, 'Porcine Endogenous Retrovirus - Advances, Issues and Solutions' (2002) 9 Xenotransplantation 373, 373.
} 
The ability of PERVs to cause disease is not known and the nature, existence and means for detecting them the subject of research, ${ }^{24}$ but animal retroviruses have adapted and spread within the human population and there is 'mounting evidence that both [Human $\mathrm{T}$ cell Lymphotropic Virus] and HIV entered the human population through multiple interspecies transmission events, from nonhuman primates. ${ }^{25}$ There are precedents for other forms of cross-species disease transmission, often with devastating results, including swine flu, Ebola, and new variant Creutzfeld-Jacob disease. In their report for the UK's Department of Health, Muir and Griffin list 26 RNA viruses and seven DNA viruses which may pose an infection risk to xeno-recipients. The risk of spreading an infectious disease following a xenotransplant (from the xeno-recipient and then to others) will depend on a number of factors including the identification of the existence of infectious diseases which are capable of replication and transmission, the nature and length of exposure to the disease, the health of those involved and the status of their immune system.

To date there is no evidence that PERVs have been transmitted to human recipients of pig cells or tissues, ${ }^{26}$ but the studies have been criticised for, amongst other things, limited exposure times to the cells and tissues, not being long-term studies of immunosuppressed recipients $^{27}$ and, crucially, no human recipients of genetically engineered solid pig organs have been studied as no such xenotransplants have been performed. Thus, 'the studies do not

\footnotetext{
${ }^{24}$ Petersen et al. (n 17) at 100.

${ }^{25}$ Muir and Griffin (n 18) at 38.

${ }^{26}$ See, for example, ME Winkler and others, 'Analysis of Pig-to-Human Porcine Endogenous Retrovirus Transmission in a Triple-Species Kidney Xenotransplantation Model' (2005) 17 Transplantation International 848; DA Cunningham and others, 'Analysis of Patients Treated with Living Pig Tissue for Evidence of Infection by Porcine Endogenous Retroviruses' (2001) 11 Trends in Cardiovascular Medicine 190; K Paradis and others, 'Search for Cross Species Transmission of Porcine Endogenous Retrovirus in Patients Treated with Living Pig Tissue' (1999) 285 Science 1236.

${ }^{27}$ Louz, et al. (n 22).
} 
fully capture the risk of transmission and offer a limited possibility to extrapolate the findings to future clinical xenotransplantation of whole organs'.28

Alongside these retroviruses, there are bacteria, fungi, parasites and other viral pathogens which may be transmitted following any transplant, ${ }^{29}$ but some of these may be minimised or eliminated by breeding the pigs in specific-pathogen free facilities, selective breeding, or early weaning, ${ }^{30}$ but this is not possible for PERVs as there are multiple copies of these retroviruses in every pig genome. Nevertheless, some have suggested that PERVs can be controlled $^{31}$, and others that the infectious risks can only be reliably determined by allowing clinical trials. ${ }^{32}$ At the Congress of the International Xenotransplantation Association in 2007 there was said to be a consensus that as long as there was 'appropriate monitoring', PERVs should not prevent clinical trials. ${ }^{33}$

The second risk from xenotransplantation is perhaps even more worrying, with Sykes stating that 'the greatest remaining risk comes from non-PERV unknown viruses that may be nonpathogenic in source animals but could adapt and become pathogenic in immunosuppressed humans'.34 Muir and Griffin highlighted examples of recent 'emerging and imported infections', including Nipah virus and swine hepatitis E virus, ${ }^{35}$ and noted that there were '[c]ertain porcine viruses [which] may have the potential, if given the opportunity, to infect

\footnotetext{
${ }^{28}$ Ibid at 61.

${ }^{29}$ See Muir and Griffin (n 18), at Ch. 3.

${ }^{30}$ Petersen et al. (n 17); H-J Schuurmann, RN Pierson, 'Progress Towards Clinical Xenotransplantation' (2008) 13 Frontiers in Bioscience 204.

${ }^{31}$ For example, B Dieckhoff and others, 'Distribution and expression of porcine endogenous retroviruses in multi-transgenic pigs generated for xenotransplantation' (2009) 16 Xenotransplantation 64; U Fiebig and others, 'Neutralizing Antibodies Against Conserved Domains of p15E of Porcine Endogenous Retroviruses: Basis for a Vaccine for Xenotransplantation?' (2003) 307 Virology 406.

${ }^{32}$ See, for example, Louz, et al. (n 22); JA Fishman, 'Screening of Source Animals and Clinical Monitoring for Xenotransplantation' (2007) 14 Xenotransplantation 349.

${ }^{33}$ CG Groth, 'Editorial - Looking Back, Heading Forward' (2008) 15 Xenotransplantation 1, 1.

${ }^{34}$ M Sykes, '2007 IXA Presidential Address: Progress Toward an Ideal Source Animal: Opportunities and Challenges in a Changing World' (2008) 15 Xenotransplantation 7, 10.

${ }^{35}$ Muir and Griffin (n 18), at 102 and Ch. 4 generally.
} 
new host species ... through a process of adaptation, even though human infection has, as yet, never been observed. ${ }^{36}$ They also describe other organisms which are known to infect pigs but which do not occur in the UK otherwise than via rare imported cases. ${ }^{37}$ Emerging infectious diseases have also been recently identified in allotransplants. ${ }^{38}$ Such unknowns are problematic, not least because our ability to detect them could be hampered by the fact that they may be unidentified (unidentifiable?) for some years after a genetically engineered solid organ pig-to-human xenotransplant has been performed. Identification may not occur for several generations after the initial xenotransplant and, by then, the undetected diseases could have spread to the wider community.

Although the precise nature and extent of the infectious disease risks posed by xenotransplantation are unclear, regulators have acknowledged their presence and outlined surveillance and monitoring regimes with which xeno-recipients and their close contacts must comply. ${ }^{39}$ The existence and content of these regimes indicate that the risks of xenotransplantation are not to be taken lightly and are viewed as more than minimal. For example, in the US it has been proposed that those receiving a xenotransplant and their 'intimate contacts' 40 should 'defer indefinitely' from donating whole blood, blood

\footnotetext{
${ }^{36}$ Ibid at 104 .

${ }^{37}$ Ibid at 105-108.

${ }^{38}$ L Scobie, Y Takeuchi, 'Porcine Endogenous Retrovirus and Other Viruses in Xenotransplantation' (2009) 14 Current Opinion in Organ Transplantation 175.

${ }^{39}$ For example see UKXIRA (n 15); Health Canada, Proposed Canadian Standard for Xenotransplantation (1999) Health Canada.

${ }^{40}$ Defined as "persons who have engaged in activities that could result in intimate exchange of body fluids, including blood or saliva, with a xenotransplantation product recipient. Examples of intimate contacts include: a. sexual partners, b. household members who share razors or toothbrushes, c. individuals who have repeated exposure to blood and bodily fluids through percutaneous inoculation (such as accidental needlestick) or through contact with an open wound, non-intact skin, or mucous membranes.' US Department of Health and Human Services (DHHS), Food and Drug Administration, Center for Biologics Evaluation and Research, Guidance for Industry: Precautionary Measures to Reduce the Possible Risks of Transmission of Zoonoses by Blood and Blood Products from Xenotransplantation Product Recipients and Their Intimate Contacts (2002), para IV. A. 2: http://www.fda.gov/downloads/BiologicsBloodVaccines/GuidanceComplianceRegulatoryInformation/Guidance s/Blood/ucm080375.pdf.
} 
components, ${ }^{41}$ and that as an 'interim precautionary measure ... tissues, breast milk, ova, sperm, or any other body parts for use in humans' are also not donated. ${ }^{42}$ Xeno-recipients who may consider reproduction in the future should be aware that there may be a 'potential risk of transmission of xenogeneic infectious agents not only to their partner but also to their offspring during conception, embryonic/fetal development and/or breast-feeding. ${ }^{43}$ Xenorecipients should be the subject of life-long surveillance 'for adverse clinical events potentially associated with xenogeneic infections', with biologic specimens archived for 50 years post-xenotransplant, ${ }^{44}$ and a complete autopsy when the xeno-recipient dies is also 'important.' 45

\section{B. Pre-clinical and clinical trials of xenotransplantation}

Pre-clinically, non-human primates have received genetically engineered pig solid organ xenotransplants and it has been reported that an orthotopic life supporting heart xenotransplant has survived for 57 days, ${ }^{46}$ a liver for eight days, ${ }^{47}$ and a kidney for 90 days. ${ }^{48}$ On the face of it limited survival times have been achieved, but for Petersen et al., 'significant progress' has been made, the results indicate that some of the barriers to xenotransplantation may have been overcome, and the time for clinical trials is approaching. ${ }^{49}$ However, whilst Sykes is fairly optimistic about the prospects and timing of clinical xenotransplants, she also acknowledges that 'we have not yet achieved long-term life-supporting xenograft survival in primates, so we have little information about physiologic

\footnotetext{
${ }^{41}$ Ibid at paras IV. A. 1 and 2.

${ }^{42}$ US DHHS, PHS Guideline on Infectious Disease Issues in Xenotransplantation (2001) DHHS, at para. 2.5.11.

${ }^{43}$ Ibid at para 2.5.12.

${ }^{44}$ Ibid at paras. 4.1.1.1 and 4.1.2. Also para. 2.5.7.

${ }^{45}$ Ibid at para. 2.5.9.

${ }^{46}$ CGA McGregor and others, 'Preclinical Orthotopic Cardiac Xenotransplantation' (2009) 28 The Journal of Heart and Lung Transplantation S224.

47 JB Cabezuelo and others, 'Assessment of Renal Function During the Postoperative Period Following Liver Xenotransplantation From Transgenic Pig to Baboon' (2002) 34 Transplantation Proceedings 321.

${ }^{48} \mathrm{~N}$ Baldan and others, 'Ureteral Stenosis in HDAF Pig-to-Primate Renal Xenotransplantation: A Phenomenon Related to Immunological Events?' (2004) 4 American Journal of Transplantation 475.

${ }^{49}$ Petersen et al. (n 17), at 93.
} 
barriers or infectious risks in this setting. ${ }^{50}$ Clinically, nine months is the longest a human has survived with a non-human animal solid organ, in this case a chimpanzee kidney. ${ }^{51}$. A baboon's heart has supported human life for 20 days, ${ }^{52}$ and a baboon's liver has survived for 70 days. $^{53}$ But there has been no report of a solid organ non-human animal to human xenotransplant since $1993^{54}$ and, crucially, a genetically engineered pig solid organ is yet to be xenotransplanted into a human.

As the barriers to xenotransplantation have yet to be pre-clinically addressed, there is limited evidence that genetically engineered pigs will be a source of viable organs. It is not known whether such an organ will be able to support the life of a human, neither is it clear what risks the xeno-recipient and others may be exposed to. Despite these uncertainties, researchers continue to work towards clinical trials, with some suggesting these are 'imminent' ${ }^{55}$ It is thus essential to consider the more theoretical question of whether to allow trials which may benefit a few but jeopardise the health of many more and, first, the practical question of how, if permitted, such trials are regulated.

\section{The Regulation of Xenotransplantation in the UK}

Between 1997 and 2006 xenotransplantation in the UK was regulated by the United Kingdom Xenotransplantation Interim Regulatory Authority (UKXIRA), ${ }^{56}$ but on 12 December 2006 the DH announced that UKXIRA had ceased to exist and new guidance on the biotechnology

\footnotetext{
${ }^{50}$ Sykes (n 34), at 11.

${ }^{51}$ K Reemtsma and others, 'Renal Heterotransplantation in Man' (1964) 160 Annals of Surgery 384.

${ }^{52}$ LL Bailey and others, 'Baboon-to-Human Cardiac Xenotransplantation in a Neonate' (1985) 254 Journal of the American Medical Association 3321.

${ }^{53}$ TE Starzl and others, 'Baboon-to-Human Liver Transplantation' (1993) 341 The Lancet 65.

${ }^{54}$ It was reported that a pig heart was xenotransplanted into a human in India in 1996, but this has been contested and the results have not been published: KS Jayaraman, 'Pig Heart Transplant Surgeon Held in Jail' (1997) 385 Nature 378.

55 See, for example, S-K Templeton, 'Lord Winston to farm pigs for transplants' The Sunday Times 7 September 2008; R Winston, 'Britain squanders pioneer work on organ transplants' The Sunday Times 7 September 2008.

${ }^{56}$ See http://www.advisorybodies.dh.gov.uk.
} 
was issued. ${ }^{57}$ In the UK, xenotransplantation should now only occur if there is 'an adequate regulatory framework in place', infection transmission from non-human to human animal is minimised and patients are traced and subject to ongoing surveillance. ${ }^{58}$ It is recommended that all xenotransplants are carried out within a research context, with a research protocol and appropriate approval from a research ethics committee obtained, because 'the well-being of the individuals concerned, and the safety of the public in general, must be foremost in the consideration of any proposal to undertake a xenotransplantation procedure' ${ }^{59}$ The guidance makes it clear that there are three different scenarios in which a xenotransplant may be performed in the UK: (i) under a clinical trial within the Medicines for Human Use (Clinical Trials) Regulations 2004, (ii) as research involving NHS patients which falls outside of the 2004 Regulations, or (iii) as experimental medicine, defined as 'a clinician offer[ing] a particular course of treatment tailored to a particular patient's needs, either a brand new treatment or a new use of a drug or product licensed for use in other ways ${ }^{60}$ With regards to the latter, the guidance suggests that those considering offering xenotransplantation as experimental treatment outside a research framework "take public health issues and longterm health surveillance of patients into account". 61

\section{OUR MODEL OF RISK}

Even though a solution to the chronic shortage of organs available for transplantation is needed, the promise of this biotechnology is unclear, uncertain and its use potentially risky. But what does this mean? The concept of risk is employed in numerous ways and attributed

\footnotetext{
${ }^{57} \mathrm{DH}$, (n 16), which replaced HSC 1998/126 Clinical Procedures Involving Xenotransplantation.

${ }^{58} \mathrm{DH},(\mathrm{n} \mathrm{16)}$, at 1-2.

59 Ibid at 2. For further discussion see S Fovargue, “"Oh Pick Me, Pick Me": Selecting Participants for Xenotransplant Clinical Trials' (2007) 15 Medical Law Review 176.

${ }^{60}$ Ibid at 3.

${ }^{61}$ Ibid at 4.
} 
varying meanings. ${ }^{62}$ Non-technically, it refers to the possibility that an undesirable consequence might occur. ${ }^{63}$ When risk is coupled with uncertainty, further definitional difficulties occur. In some theories a distinction is drawn between uncertainty and risk, so if a number of events may occur following a course of action, but the likelihood of their occurrence is unknown, the situation is presented as one of uncertainty. If the possible events that may occur are known as well as the probabilities of their occurring, the situation can be characterised as involving risks. ${ }^{64}$ Such a distinction is misleading. To refer to a course of action as posing a risk of harm necessarily implies some degree of uncertainty. ${ }^{65}$ Whilst knowing the probability of a known possible outcome makes it a more concrete risk, uncertainty will remain in terms of whether it will actually occur and all of its consequences. Moreover, simply because there is a higher level of uncertainty about the probability of a possible outcome occurring, this does not move it from a risk to an uncertainty because so long as it may occur, it remains a risk. A risk must involve an element of uncertainty in order for it to be a risk. ${ }^{66}$ Definitionally, it does not matter that some risks are more certain than others. Thus, the fact that the potential negative outcomes of xenotransplantation are uncertain does not preclude describing these possible outcomes as risks.

The language of risk is, however, problematic as risk can refer to (i) the negative outcome itself, (ii) the probability of a certain negative outcome, (iii) adopting a hazardous course of action, or (iv) endangering something. So, (i) lung cancer is the risk of smoking, (ii) there is

\footnotetext{
${ }^{62}$ L Zedner, 'Fixing the Future? The Pre-emptive Turn in Criminal Justice' in B McSherry, A Norrie and S Bronitt (eds), Regulating Deviance: The Redirection of Criminalisation and the Futures of Criminal Law (2008) Hart, 39; S Carter, 'Boundaries of Danger and Uncertainty: An Analysis of the Technological Culture of Risk Assessment' in J Gabe (ed.) Medicine, Health and Risk - Sociological Approaches (1995) Blackwell, 134-135;

${ }^{63}$ SO Hansson, 'Philosophical Perspectives on Risk' (2004) 8 Techné 10. Risk is a social construction, but this is not our focus: see further D Lupton, 'Risk as Moral Danger: The Social and Political Functions of Risk Discourse in Public Health' (1993) 23 International Journal of Health Services 425; Beck (1992) ( n 13).

${ }^{64}$ PH Van Ness, 'The Concept of Risk in Biomedical Research Involving Human Subjects' (2001) 15 Bioethics 365.

${ }^{65}$ Zedner (n 62), at 44.

${ }^{66}$ See Hansson (n 63), at 11; Carter (n 62), at 135.
} 
a real risk that smoking could lead to lung cancer, (iii) those who smoke run the risk of lung cancer in later life, or (iv) those who smoke risk their health. We primarily utilise risk in the first and second senses, as our understanding of xenotransplantation and its risks leads us to consider that moving to clinical trials presents uncertain risks of a grave nature. Xenotransplantation creates an environment of 'manufactured risk ${ }^{, 67}$, risk which is created by the progression of science and (bio)technology; risk that we have no prior experience of that enables us to calculate the probability of negative outcomes occurring.

Our model of risk also draws upon the logic of lesser harms: it is legitimate to proceed with a medical innovation if the risks it poses are lower than the risks of the condition which the innovation is intended to treat. ${ }^{68}$ Thus, research should not progress to clinical trials if the risks of it are too serious. ${ }^{69}$ With xenotransplantation, there is more than a risk that the individual who needs a xenotransplant will die without a transplant; this is the likelihood, if not the certainty. ${ }^{70}$ If it were simply a case of balancing this likelihood against the risks of having a xenotransplant as part of a clinical trial, then xenotransplantation would win. The risk of death posed by a xenotransplant also comes with a chance of survival, no matter how slight, and even if death results as a consequence this is no different than the probable outcome of the individual's condition. But when considering the risks posed by moving to clinical trials, account must surely also be taken of risks to others and the potential benefits to society by enhancing medical knowledge and potentially finding a solution to the shortage of organs for transplantation. However, it is increasingly being perceived to be morally impermissible for scientists to knowingly expose the public to manufactured risks, ${ }^{71}$ and the moral impermissibility of this must, in part, be dependent on how great the risk is. According

\footnotetext{
${ }^{67}$ A Giddens, 'Risk and Responsibility' (1999) 62 Modern Law Review 1, 4, emphasis in original.

${ }^{68}$ SA Halpern, Lesser Harms: The Morality of Risk in Medical Research (2006) University of Chicago Press, 4.

69 Ibid at 17.

${ }^{70}$ For discussion of the proposed first xeno-recipients see Fovargue (n 59).

${ }^{71}$ Ravelingien (n 7), at 134.
} 
to Gostin, measures taken to protect public health should be based on significant risks not just 'speculative, theoretical, or remote' ones, and in order to assess the level of a risk, account should be taken of the nature and duration of it, the probability of the harm occurring, and the severity of it. ${ }^{72}$

Although we cannot measure or quantify the risks involved in clinical xenotransplantation, it is surely more dangerous to proceed in the face of the possible risks of it than not to because:

[i]f the recognition of a risk is denied on the basis of an 'unclear' state of information, this means that the necessary counteractions are neglected and the danger grows. By turning up the scientific standard of accuracy, the circle of recognized risks justifying action is minimized, and consequently, scientific license is implicitly granted for the multiplication of risks. ${ }^{73}$

Why should we need to wait for scientifically ascertained probabilities as to the occurrence of the risk of an infectious disease pandemic in order to determine that this risk is serious enough to prevent xenotransplantation from progressing to clinical trials? If we could ascertain that the probability of the risk of such harm occurring was very low, scientific rationality would lend itself to the conclusion that the potential benefits of moving to clinical trials would outweigh this unlikely risk. ${ }^{74}$ But would and should this be enough to satisfy the public? Even if the risk of an infectious disease pandemic occurring is very low, it is still there and it is a risk of severe harm. Drawing an analogy between the risks of xenotransplantation and those posed by nuclear power plants, Daar discusses the low chances of 'China Syndrome' occurring; a nuclear meltdown with the consequent release of

\footnotetext{
${ }^{72}$ LO Gostin, Public Health Law: Power, Duty, Restraint $2^{\text {nd }}$ ed. (2008) University of California Press, 57.

${ }^{73}$ Beck (1992) (n 13), at 62, emphasis in original.

${ }^{74}$ Ibid at 29-30.
} 
radioactive material into the environment. ${ }^{75}$ Using estimates of quantifiable risks on the basis of the probability of accidents, scientists rationalise that this risk is acceptable. ${ }^{76}$ But no matter how improbable, were a nuclear meltdown to happen the consequences would be devastating, as the Chernobyl Disaster in 1986 demonstrates. ${ }^{77}$ And scientists, of course, cannot provide any definite answer as to the probability of a negative outcome occurring, with experts frequently failing to reach agreement as to the levels at which hazards posed by a biotechnology are acceptable, especially in the context of manufactured risk. For these reasons, demanding that the risks posed by xenotransplantation are assessed as unacceptable on the basis of probability in order to halt clinical trials is unreasonable. But what does this mean for an individual who needs a xenotransplant to improve their health, and for the wider public health?

\section{INTEREST IN THE HEALTH OF INDIVIDUALS AND XENOTRANSPLANTATION}

\section{A. General}

It is indisputable that the state has an interest in the health of the individuals which comprise it and this can mean establishing health care systems which provide appropriate care to those in need in a timely manner. These key aims of the UK's National Health Service, ${ }^{78}$ are recognised in international conventions and charters. ${ }^{79}$ Framing the individual's interest in health within a rights discourse plays an important role in presenting health as a matter that the state is responsible for. Indeed, '[v]iewing health as a fundamental right, part of the fabric of democracy and justice, transforms the social and political discourse. The language

\footnotetext{
75 AS Daar, 'Xenotransplantation: Science, Risk and International Regulatory Efforts', in Caulfield and Williams-Jones (eds.), The Commercialization of Genetic Research: Ethical, Legal and Policy Issues (1999) Kluwer Academic/Plenum Publishers, 129, 150-1.

${ }^{76}$ Beck (1992) (n 13), at 29-30.

${ }^{77} \operatorname{Daar}(\mathrm{n} 75)$.

${ }^{78}$ National Health Service Act 1946; National Health Service Act 2006.

${ }^{79}$ Article 25 Universal Declaration of Human Rights 1948; Articles 11 and 13 European Social Charter 1961.
} 
of 'rights' suggests that states have obligations and can be held accountable for violations' ${ }^{80}$ Judicial comments also indicate that such a right is evolving and may be encompassed under the right to life in Article 2 of the European Convention on Human Rights (ECHR) and the Human Rights Act $1998 .^{81}$

The interest in individual health has, in some countries, taken on a particular focus. In the UK and the US this interest has translated into a trend of giving legal and ethical priority to an individual's autonomy regarding her health. However, although Article 8 of the ECHR has been held to protect personal autonomy in the shape of a right to bodily integrity, ${ }^{82}$ legal recognition of individual rights is not absolute. ${ }^{83}$ The House of Lords and the European Court of Human Rights have held that recognition of a personal autonomy right under Article 8 can take second place to the need to protect the rights of vulnerable others. ${ }^{84}$ The apparent precedence given to individual autonomy in bioethics has been critiqued, ${ }^{85}$ and alternative presentations of autonomy offered. ${ }^{86}$ Thus although individual interests, personal autonomy and rights are legally and ethically recognised, they can sometimes be offset by other public and private interests.

\section{B. Applied to xenotransplantation}

\footnotetext{
${ }^{80} \operatorname{Gostin}(\mathrm{n} 72)$, at 278.

${ }^{81}$ For example, Osman v UK (1998) 29 EHRR 245. But note O'Neill's important caveat that this can only be 'a right to health care of a certain level' since it is impossible 'to guarantee health for all': O O'Neill, Autonomy and Trust in Bioethics (2002) Cambridge University Press, 79.

${ }^{82} R$ (Pretty) v DPP [2002] 1 AC 800; An NHS Trust A v M and An NHS Trust B v H [2001] Fam. 3481.

${ }^{83} R$ (on the application of Burke) $v$ GMC, [2005] EWCA Civ 1003; $R v$ North West Lancashire Health Authority, ex parte A, D and G [2000] 1 WLR 977.

${ }^{84} R$ (Pretty) v DPP; Pretty $v$ UK [2001] 1 All ER 1.

${ }^{85}$ See, for example, M Brazier, 'Do No Harm - Do Patients Have Responsibilities Too?' (2006) 65 Cambridge Law Journal 397; A Dawson, E Garrard, 'In Defence of Moral Imperialism: Four Equal and Universal Prima Facie Principles' (2006) 32 Journal of Medical Ethics 200.

${ }^{86}$ See, for example, N Manson, O O’Neill, Rethinking Informed Consent in Bioethics (2007) Cambridge University Press.
} 
If the state prohibits xenotransplantation, individuals who need a xenotransplant will be deprived of a chance of survival. But we should not assume that an individual's health will be enhanced by a xenotransplant. ${ }^{87}$ Given their experimental nature, they are unlikely to bring about a positive outcome for participants in early trials. ${ }^{88}$ McLean and Williamson have predicted that 'it is likely that in any early trials that take place the transplants will fail; if the treatment in question is the transplant of a whole organ then it is also likely that the patient will die. ${ }^{89}$ Ideas of benefit for xeno-recipients have been reinforced by the World Health Organization (WHO) ${ }^{90}$ but these ideas do not necessarily mean that the individual's interest will not be served by participation in clinical trials. Perhaps the would-be participant is realistic about her chances of survival. Her primary reason for involvement is not so much prolonging her own life, but saving the lives of others in the future who may face her predicament. ${ }^{91}$ Nonetheless, when balancing the individual interest in health against public health interests, the likelihood of a positive outcome for the recipient's health must be taken into account. However, if the validity of prohibiting xenotransplantation on the basis of the uncertain risk is challengeable, then so to is permitting it on the basis of uncertain benefit. The status quo should thus be respected and xenotransplantation not clinically proceed.

Prohibiting xenotransplantation could be viewed as infringing the autonomy of would-be participants by breaching the negative obligation of individual autonomy - 'autonomous actions should not be subjected to controlling constraints by others. ${ }^{92}$ However, is agreeing to participate in a xenotransplant clinical trial really an affirmative expression of individual

\footnotetext{
${ }^{87}$ For discussion of the requirement for benefit with regards to xenotransplant clinical trials see S Fovargue, 'A Leap of Faith? Sanctioning Xenotransplant Clinical Trials' (2005) 26 Liverpool Law Review 125.

${ }^{88}$ Ibid.

${ }^{89}$ McLean and Williamson (n 6) at 175.

90 'First WHO Global Consultation on Regulatory Requirements for Xenotransplantation Clinical Trials, Changsha, China, 19-21 November 2008' (2009) 16 Xenotransplantation 61.

${ }^{91}$ Fovargue (n 87).

92 TL Beauchamp, JF Childress, Principles of Biomedical Ethics $6^{\text {th }}$ ed (2009) Oxford University Press, 104.
} 
autonomy? In order to fulfil the positive obligation of autonomy, which requires ' $\mathrm{r}$ ] espectful treatment in disclosing information and actions that foster autonomous decision making, ${ }^{93}$ the surgeon performing the xenotransplant must provide the necessary information for a person to make an informed decision. This will not be easy given the limited information available on xenotransplantation. And an individual consenting to participate in a xenotransplant trial might not be truly exercising individual autonomy because it will lead to such a severe infringement of their personal autonomy in the future. ${ }^{94}$ Is it possible to give fully informed consent to as-of-yet unexperienced severe liberty limiting measures which could include a lifelong surveillance and monitoring regime, remaining within it, refraining from having children, and compulsory post-mortems? ${ }^{95}$ The law does not require an individual to have experienced treatments and health care options to give a fully informed refusal to them, ${ }^{96}$ but the situation here is very different. In xenotransplantation the individual is consenting to a medical intervention which will lead to unexperienced potentially severe lifelong restrictions on liberty. Other issues arise in relation to the nature of enforcement and sanctions for non-compliance, and also whether contacts of the xenorecipient should be required to consent to it and comply with such a regime. ${ }^{97}$ Even taking into account individual interests and autonomy, xenotransplantation has serious implications for the xeno-recipient, their contacts and the wider public. We thus contend that there are some things which are 'inherently wrong - that is, wrong no matter how much good could come from doing [them] ${ }^{, 98}$ and that xenotransplantation falls into this category.

\section{INTERESTS IN PUBLIC HEALTH, THE HEALTH OF THE PUBLIC AND XENOTRANSPLANTATION}

\footnotetext{
93 Ibid.

${ }^{94}$ S Fovargue, 'Consenting to Bio-Risk: Xenotransplantation and the Law' (2005) 25 Legal Studies 404.

${ }^{95}$ See, for example, UKXIRA (n 15).

${ }^{96}$ B v NHS Hospital Trust [2002] EWHC 429.

97 For discussion of some of these issues see PS Florencio, ED Ramanathan, 'Are Xenotransplantation Safeguards Legally Viable?' (2001) 16 Berkeley Technology Law Journal 937.

${ }^{98}$ Sommerville (n 12), at 25.
} 


\section{A. General}

There are various definitions of 'public health' and the UK's Faculty of Public Health suggests that, amongst other things, it 'emphasises collective responsibility for health, its protection and disease prevention". ${ }^{99}$ It may thus be in society's interest for the state to take preventative action to protect public health. This interest in public health not only imposes a significant burden on the state but also lends support to ideas of a collective right to public health or, at the very least, an expectation that the state will take necessary measures to ensure it. Whilst rights to health have not been explicitly recognised in English law, international and European conventions recognise the importance of health in general terms and set out States' obligations in respect of health. ${ }^{100}$ There are also domestic legal provisions, powers and duties under which actions taken in order to protect the health of the population can be based. ${ }^{101}$ And English law recognises that there are situations where public health can legitimate action that will hinder an individual's interests when this action is taken not by the state, but by individuals working within the health care system. ${ }^{102}$

Public health thus cares about individuals as themselves because a population is healthy only if those within it are 'relatively free from injury and disease'. ${ }^{103}$ However, its 'abiding interest is in the well-being and security of populations, not individual patients'. ${ }^{104}$ As such, it can bring into conflict private and public rights. ${ }^{105}$ Nevertheless, there is a sense that the state can and should take action in certain situations in the name of public health, such as the

\footnotetext{
99 The Faculty of Public Health: www.fphm.org.uk/about faculty/what public health/default.asp, emphasis added. See also M Verweij, A Dawson, 'The Meaning of 'Public' in "Public Health"' in A Dawson, M Verweij (eds.) Ethics, Prevention and Public Health (2007) Oxford University Press, 14-16.

${ }^{100}$ For example, Article 25 Universal Declaration of Human Rights 1948, Article 11 European Social Charter of 1961, Article 12 International Covenant on Economic, Social and Cultural Rights; Article 152 amended EC Treaty.

101 For example, Health Act 2006. For details of the five relevant regulations see http://www.smokefreeengland.co.uk; the amended Public Health (Control of Disease) Act 1984.

${ }^{102}$ Wv Egdell [1990] Ch 359. See also General Medical Council (GMC), Confidentiality (2009) GMC, para. 37.

${ }^{103} \operatorname{Gostin}(\mathrm{n} 72)$, at 17.

104 Ibid.

${ }^{105}$ P Old, J Montgomery, 'Law, Coercion, and the Public Health' (1992) 304 British Medical Journal 891.
} 
implementation of measures to remove causes of ill health and prevent epidemic diseases. The responses to swine flu globally during 2009 support this contention. ${ }^{106}$

\section{B. Applied to xenotransplantation}

Interest in public health requires the state to take measures to remove causes of ill health and prevent epidemic diseases and it could demand a precautionary, evidence-based approach to xenotransplantation. In fulfilling its obligations and responsibility to the public, the UK state might have a duty to ban xenotransplantation because of the significant risk of harm to health it poses. Failure to prohibit xenotransplantation arguably means the state would knowingly be permitting the public's exposure to serious risks which cannot currently be quantified and thus controlled or appropriately managed. Conversely, the public interest in health could require the state to encourage xenotransplantation to save or prolong individual lives, as less suffering and ill health is beneficial to the wider community and the health of us all, and if xenotransplantation is successful the shortage of organs could be resolved, making resources available for other treatments.

Yet just because there are possible gains for public health and individual interests, this does not mean that it should be automatically assumed that xenotransplantation will and should proceed to clinical trial. A parallel can be drawn with reproductive cloning. As another new science, public health may have benefited from the introduction of an additional method of combating infertility, and the individual interest in having a biologically related child would have been served by its clinical application. Notwithstanding this, reproductive cloning remains unlawful in the UK. ${ }^{107}$ The prohibition is undoubtedly in part because reproductive cloning is a symbolic wrong that seems to violate the value of respect for human life and

\footnotetext{
${ }^{106}$ For further information see http://news.bbc.co.uk/1/hi/in_depth/world/2009/swine_flu/default.stm.

${ }^{107}$ First under section 1 of the Human Reproductive Cloning Act 2001, and now under section 3 of the Human Fertilisation and Embryology Act 2008.
} 
dignity, ${ }^{108}$ but a further justification is the potential harm to the clone due to birth defects. ${ }^{109}$ That it is unclear how likely the occurrence of this harm would be, as with xenotransplantation, has not prevented such prohibition, perhaps because there is a real risk that it could be severe. ${ }^{110}$

Even if xenotransplantation could solve the organ shortage, the potential public health benefits would need to outweigh the risks to justify going ahead with it - the condition of proportionality. ${ }^{111}$ This is hard to satisfy. Societal public health is likely to suffer more of a detriment from the severity of the potential risk of an infectious disease pandemic than the benefit potentially achieved through increased organs available for transplantation. ${ }^{112}$ Everyone in society is placed at risk of a pandemic by allowing xenotransplantation to proceed. As a consequence, society's infrastructure might collapse; indeed, we have been living with this possibility since early 2009 with regard to the global swine flu pandemic. In the UK, for example, many businesses and organisations, including universities, have drawn up contingency plans in the event that individuals are infected. The risk of a pandemic caused by xenotransplantation and its possible impact can be contrasted with the limited negative impact on public health caused by the shortage of organs for transplantation. Without minimising or being unsympathetic to the harm that those requiring a (xeno)transplant may suffer, it is the health of a limited number in society which is directly affected, rather than society's capacity to function. Applying lesser harms reasoning, the health of the more limited number in society should be outweighed by the risk of harm posed

\footnotetext{
${ }^{108}$ B Steinbock, 'Liberty, Responsibility and the Common Good' (1996) 26 Hastings Center Report 45.

${ }^{109}$ See, for example, KL Macintosh, Illegal Beings: Human Clones and the Law (2005) Cambridge University Press, Part One.

${ }^{110}$ See, for example, The President's Council on Bioethics, Human Cloning and Human Dignity: An Ethical Inquiry (2002) Washington DC, 89, 90, 92.

111 JF Childress and others, 'Public Health Ethics: Mapping the Terrain' (2002) 30 Journal of Law, Medicine and Ethics 170, 173.

${ }^{112}$ See D Callahan, 'Principlism and Communitarianism' (2003) 29 Journal of Medical Ethics, 287, 291.
} 
by moving forward with xenotransplantation. This argument is strengthened by applying the precautionary principle modified by the harm principle.

\section{A PRECAUTIONARY APPROACH}

The precautionary principle, most often used in environmental policy, essentially holds that 'where there are threats of serious and irreversible damage, lack of full scientific certainty shall not be used as a reason for postponing cost-effective measures to prevent environmental degradation. ${ }^{113}$ Although there is no one agreed definition of it, the precautionary principle is underpinned by a number of key ideas. First, that 'when faced with an unknowable and unquantifiable risk that cannot be ruled out, actions should be taken in advance to minimize that risk'. ${ }^{114}$ The principle is thus directed at anticipation rather than cure. ${ }^{115}$ The common sense themes of 'if in doubt, err on the side of caution' and 'it's better to be safe than sorry' are also identifiable in the different conceptions of the principle. If the principle is used to determine public policy, then morally unacceptable harms which may result from human actions should be avoided or diminished. Even if the harms are uncertain, 'it is sufficient that they be scientifically plausible'. ${ }^{116}$ The WHO has described the principle as 'a risk management policy applied in circumstances with a high degree of scientific uncertainty, reflecting the need to take action for a potentially serious risk without awaiting the results of scientific research. $^{117}$ It thus enables regulators to constrain or prohibit risky technology, even in circumstances where the risks are scientifically uncertain and other factors might

\footnotetext{
${ }^{113}$ United Nations Rio Declaration on Environment and Development 1992, principle 15: http://www.unep.org.

114 JM Kress, 'Xenotransplantation: Ethics and Economics' (1998) 53 Food and Drug Law Journal 353, 378.

${ }^{115}$ L Boisson de Chazournes, 'New Technologies, the Precautionary Principle, and Public Participation' in T Murphy, T., (ed), New Technologies and Human Rights (2009) Oxford University Press, 166.

${ }^{116}$ K Steele, 'The Precautionary Principle: A New Approach to Public Decision-Making' (2006) 5 Law, Probability and Risk 19,19. For a discussion of "weak" and "strong" versions of it see E Soule, "Assessing the Precautionary Principle' (2000) 14 Public Affairs Quarterly 309.

117 WHO, Electromagnetic Fields and Public Health Cautionary Policies http://www.who.int/docstore/peh-emf/publications/facts_press/EMF-Precaution.htm. 
suggest a different regulatory approach. ${ }^{118}$ The element of uncertainty is 'a sine qua non condition to the application and even to the legitimacy of the precautionary principle'. ${ }^{119}$

Whilst the principle itself is contested and has been criticised for being, amongst other things, ill-defined, absolutist and marginalising science, ${ }^{120}$ it may be of use in balancing the different interests in public health because it recognises aspects of each of these interests. For example, the idea that decisions can be made in order to benefit or protect the many, as occurs under the amended Public Health (Control of Disease) Act $1984,{ }^{121}$ can be seen in the precautionary principle which promotes the curtailment of actions that pose a significant risk of harm to community interests. ${ }^{122}$ The principle acknowledges that account should be taken of damage to individuals along with that to the public and future generations, ${ }^{123}$ and inherently recognises the importance of advances in science and medicine, by focusing on appropriate responses to such developments which may harm human and environmental health. If it did not, it would advocate that uncertainty about risk equates to a moratorium on advances, and it categorically does not do this. ${ }^{124}$ As Resnik argues, provided the threats under consideration are plausible and the precautionary measures adopted reasonable, the precautionary principle is not unscientific nor does it marginalise the role of science, the condition of proportionality again. ${ }^{125}$

\footnotetext{
${ }^{118}$ Soule (n 116). For a brief discussion of other regulatory approaches see, for example, CF Cranor, 'Learning from the Law to Address Uncertainty in the Precautionary Principle' (2001) 7 Science and Engineering Ethics 313.

${ }^{119}$ Boisson de Chazournes (n 115), at 153.

${ }^{120}$ See, for example, P Sandin and others, 'Five Charges Against the Precautionary Principle' (2002) 5 Journal of Risk Research 287; GE Marchant, 'The Precautionary Principle: An "Unprincipled" Approach to Biotechnology Regulation' (2001) 4 Journal of Risk Research 143; T O’Riordan, A Jordan, 'The Precautionary Principle in Contemporary Environmental Politics' (1995) 4 Environmental Values 191.

${ }^{121}$ As amended by the Health and Social Care Act 2008.

${ }^{122}$ Steele (n 116), at 24.

${ }^{123}$ Ibid.

${ }^{124}$ See, for example, arguments discussed in Sandin et al. (n 120).

${ }^{125}$ DB Resnik, 'Is the Precautionary Principle Unscientific?' (2003) 34 Studies in History and Philosophy of Biological and Biomedical Sciences 329.
} 
This means that in situations where there are recognised harms to human health but the extent of those harms is not known, as with most clinical trials, then the person proposing the trial has the burden of proof with regards to risks, and immediate action is required in order to forestall potentially serious consequences to health in the future. ${ }^{126}$ Andorno comments:

in view of the possibility of serious harmful effects ... it is not acceptable just to say: 'we cannot be sure that serious damage will happen, so we will do nothing to prevent it.' If there are good reasons, based on empirical evidence or plausible causal hypothesis, to believe that damage might occur, and given the crucial importance of what is at stake (the life and health of people ...), adequate measure should be taken as soon as possible to prevent such disastrous outcomes. ${ }^{127}$

In this way, the precautionary principle expands the harm principle so that it encompasses public goods and possible harm to future generations. ${ }^{128}$ Mill's harm principle thus supports our argument that in some situations (xenotransplantation being one) a precautionary approach influenced by the harm principle, should prevail.

\section{THE HARM PRINCIPLE}

Under Mill's harm principle, it is only appropriate to constrain an individual's liberty through law or moral coercion if the individual's behaviour causes harm to others. As individuals are sovereign over their own lives, any outside intervention into their lives and liberty can only

\footnotetext{
${ }^{126}$ RL Keeney, 'Appraising the Precautionary Principle - A Decision Analysis Perspective' (2001) 4 Journal of Risk Research 191, 191-2.

${ }^{127}$ R Andorno, 'The Precautionary Principle: A New Legal Standard for a Technological Age' (2004) 1 Journal of International Biotechnology Law 11, 12.

${ }^{128}$ As suggested by Steele (n 116), at 24.
} 
be justified if they act in a way that damages others. ${ }^{129}$ The notion of harm is thus central and Mill refers to acts which are 'injurious to others,' giving as examples '[e]ncroachment of their rights; infliction on them of any loss or damage not justified by his own rights; falsehood or duplicity in dealing with them; unfair or ungenerous use of advantages over them; even selfish abstinence from defending them against injury'. ${ }^{130}$ Such conduct can lead to moral reprobation when it involves a breach of duty to others, ${ }^{131}$ but it is only when an individual violates others' rights that she should be punished by law. ${ }^{132}$ However, Mill seems prepared to expand the harm principle further and refers to offences occurring in public that 'are a violation of good manners', with offences against decency an example. ${ }^{133} \mathrm{He}$ did not explain why such offences are harmful, so this construct of harm is open to broad interpretation. But it is clear that Mill did not allow for other concerns, such as moralism or paternalism, to encroach on his harm principle. ${ }^{134}$

Feinberg has clarified the character of harm in his refinement of Mill's avoidance of harm theory, and suggests there are two notions of harm: harm as a setback to an interest and harm as a wrong. Harm occurs in the form of a setback to someone's interests if one individual's behaviour thwarts another's interest thereby leaving it 'in a worse condition than it would otherwise have been in had the invasion not occurred at all' ${ }^{135}$ Interests are "things in which one has a stake" and which are vital to an individual's well-being. ${ }^{136}$ Harm as a wrong occurs when an individual wrongs another or treats her unjustly; '[o]ne person wrongs another when his indefensible (unjustifiable and inexcusable) conduct violates the other's

\footnotetext{
129 JS Mill, Utilitarianism, On Liberty, Considerations on Representative Government (1993) Orion, 78, 143144.

${ }^{130}$ Ibid at 146 .

${ }^{131}$ Ibid at 147 .

${ }^{132}$ Ibid at 143 .

${ }^{133}$ Ibid at 167 .

${ }^{134}$ LW Sumner, The Hateful and the Obscene (2004) University of Toronto Press, 40.

135 J Feinberg, The Moral Limits of the Criminal Law: Harm to Others (1984) Oxford University Press, 34.

${ }^{136}$ Ibid.
} 
right' ${ }^{137}$ When applying the harm principle, only harms which fit into both categories can legitimate legal prohibition of conduct. ${ }^{138}$ Feinberg's interpretation of the harm principle thus provides greater insight into the form of harmful behaviour that may justify legal intervention by the criminal law.

Mill's thesis is applicable to established, 'certain' concrete risks and behaviour that creates a risk of harm, because he includes behaviour that poses a 'definite risk of damage' within the remit of his harm principle. ${ }^{139}$ However, extending the harm principle to a risk of future harm makes its application less straightforward. How can we possibly know all the consequences that will emerge from our actions before we have acted? And if we also consider potential harm, will this distort and exaggerate the harm principle ${ }^{140}$ It has been suggested that it may be difficult to definitely ascertain that conduct poses no significant risk of future harm, ${ }^{141}$ and that it may be so easy now to formulate arguments predicated upon harm that the harm principle has collapsed in on itself. ${ }^{142}$ We disagree, but accept that caution must be taken when addressing harm claims in order to ensure that the harm principle remains sufficiently defined and restrictive. It is important to note that although often viewed through the lens of individual autonomy, there is no reason why Mill's harm theory cannot operate in the context of public health. ${ }^{143}$ In fact, it would arguably detract from Mill's

\footnotetext{
${ }^{137}$ Ibid at 34 , emphasis in original.

${ }^{138}$ Ibid.

${ }^{139}$ Mill (n 129), at 150.

${ }^{140}$ N Persak, Criminalising Harmful Conduct (2007) Springer-Verlag, 44-5.

${ }^{141}$ A von Hirsch, 'Extending the Harm Principle: "Remote" Harms and Fair Imputation' in AP Simester, ATH Smith, (eds), Harm and Culpability (1996) Clarendon Press, 260.

${ }_{142}$ BE Harcourt, 'The Collapse of the Harm Principle' (1999) 90 The Journal of Criminal Law and Criminology 109.

${ }^{143} \operatorname{Coggon}(\mathrm{n} 4)$, at 799.
} 
utilitarian outlook if the harm principle could not function in a way that would allow consideration of collective interests and the maximisation of utility. ${ }^{144}$

\section{APPLYING A PRECAUTIONARY APPROACH ALONGSIDE THE HARM PRINCIPLE TO THE RISKS}

\section{OF XENOTRANSPLANTATION}

To recap, we use risk to refer to the possible negative outcomes of xenotransplantation and the probability of these outcomes occurring. On the basis of the available evidence, moving to clinical trials presents uncertain risks of a grave nature, the main one being an infectious disease pandemic. Xenotransplantation poses manufactured risks, risks created by scientific progress and of which we have no prior experience; thus calculating the probability of their occurrence is especially difficult. Applying lesser harms logic, the risks posed by xenotransplantation should be lower than the risks of organ failure that it is designed to treat. Although an individual in need of a xenotransplant may die without one, the fact that xenotransplantation poses risks to others besides the recipient must be taken into account when weighing up the seriousness of risk. Finally, even if it were possible to ascertain that the probability of the risk of an infectious disease pandemic is very low, because of the serious nature of this risk, this does not make the risk acceptable.

Therefore, as xenotransplantation poses real risks of harm, and liberal and more collective concerns are relevant, we propose that the precautionary principle informed by the harm principle should be used as a guide to ascertain whether public health should be prioritised over an individual's health, even in a life prolonging situation. We have set out the key components of the precautionary principle - acting in advance of scientifically certain and established risks, anticipating risks and minimising them but not necessarily eradicating

\footnotetext{
${ }^{144}$ See generally Mill, Utilitarianism in Mill, (n 129), at 1. In On Liberty he comments: 'I regard utility as the ultimate appeal on all ethical questions; but it must be utility in the largest sense, grounded on the permanent interests of man as a progressive being', at 79 .
} 
them, and seeking to protect existing and future generations. These and other elements are all necessarily involved in clinical trials because until a drug or other intervention is tested on a human, the risks can never be known with any certainty. Educated predictions can be made, based on pre-clinical data, but the first clinical trial participant will, to some extent, always be taking a leap of faith. ${ }^{145}$ Because of this, most countries regulate clinical trials, an example of the precautionary principle in practice. So what of xenotransplantation clinical trials - are these so different to other such trials? The information presented earlier suggests they are, because of the potential risk and harm that may be caused to the xeno-recipient and others, nationally and globally. We do not have to wait for the risks or harms to materialise in order to justify acting to protect others, particularly where the effects of doing so may be so catastrophic; rather, the precautionary principle supports, and maybe even requires, anticipatory action. The harm principle, concerned as it is with individuals and others who may be harmed by the actions of the individual, supports curtailing the use of xenotransplantation and other developing biotechnologies requiring a similar weighing of private benefit and public risk. The harm principle would not, however, permit state intervention to prevent an individual from accepting a xenotransplant (assuming clinical trials proceed) on the basis of the potential harm her actions may cause to herself. Such paternalistic intervention would violate the principle. ${ }^{146}$ But if xenotransplantation endangers public health, the harm principle justifies state intervention to prevent its practice.

But what about the fact that as we can never know all of the consequences of our actions before we act, the harm principle could prohibit almost any medical advance? This argument

\footnotetext{
${ }^{145}$ See, for example, the disastrous results of the TGN1412 trial at Northwick Park in 2006: Expert Scientific Group, Expert Scientific Group on Phase One Clinical Trials: Final Report (2006): http://www.dh.gov.uk/prod_consum_dh/groups/dh_digitalassets/@dh/@en/documents/digitalasset/dh_073165.p df; Medicines and Healthcare products Regulatory Authority, Investigations into Adverse Incidents during Clinical Trials of TGN1412 (2006): http://www.mhra.gov.uk.

${ }^{146}$ Mill (n 129), at 78.
} 
is especially relevant to us as the consequences of accepting a xenotransplant are unclear and likely to remain so until a genetically engineered solid pig organ is xenotransplanted into a human. Even then, we might have to wait for a number of (unspecified) years in order to monitor any harms following from that xenotransplant. We can say that xenotransplantation poses a real risk of future harm; it is the nature and severity of that harm which is unquantifiable. But, in assessing the level of risk, it is difficult to evaluate the nature and duration of the risk, the probability of the harm occurring, and the severity of it regarding xenotransplantation. ${ }^{147}$ But, "it is [also] not possible to ascertain with any certainty that the risks posed to public health are small' ${ }^{148}$ Whilst a more specific potential harm to the public is identified to justify breaching confidentiality, ${ }^{149}$ for example, it is likely to be harm of a smaller magnitude (in terms of the number of people who might be exposed to a risk of serious harm or death) than the possible harm to health posed by xenotransplantation. And it is less problematic to apply the harm principle when the harm is concrete and ascertainable, as in $W v$ Egdell. ${ }^{150}$

The fact that the identified potential harm to 'vulnerable' individuals was not concrete and easily measurable did not prevent the European Court of Human Rights from finding that it should outweigh Dianne Pretty's personal autonomy under Article 8. ${ }^{151}$ Thus, applying the harm principle to xenotransplantation results in a prohibition on clinical trials because of the potential severity of harm that could be caused to public health. Feinberg's presentation of harm leads to a similar conclusion, as allowing clinical xenotransplantation creates the danger

\footnotetext{
${ }^{147}$ Gostin (n 72).

${ }^{148}$ McLean and Williamson (n 6), at 184.

${ }^{149} W v$ Egdell [1990] Ch 359; GMC (n 102). In the GMC guidance, the situations given as examples of circumstances where a third party needs to be protected from a risk of serious harm or death are 'when a disclosure would be likely to assist in the prevention, detection or prosecution of serious crime, especially crimes against the person', at para 54. This suggests that those at risk of serious harm or death are specific individuals who have come into contact, or will come into contact, with the patient.

${ }^{150}$ The potential harm in this case was a risk of serious injury or death to individuals who came into contact with the plaintiff, W, if Dr Egdell's considered view of W's continued dangerousness was correct.

${ }^{151}$ Pretty v UK [2001] 1 All ER 1, at para 74.
} 
of harm in the sense of a setback to individuals' interests if the risk of an infectious disease materialises. Furthermore, unless everyone at potential risk consents, it would also amount to harm in the sense of a wrong as it would violate others' right to consent.

Although researchers and potential xeno-recipients only intend to preserve life and not harm others, they are arguably reckless given the risk of harm that providing and accepting a xenotransplant creates, and should be brought to account for this. ${ }^{152}$ Researchers' have a responsibility to others besides the potential xeno-recipient, ${ }^{153}$ and 'it could be argued that the numerous studies showing the possibility of widespread viral outbreaks prove such injury was reasonably foreseeable to the companies, medical centers and individuals performing xenotransplantation. ${ }^{154}$ We could add research ethics committees to this list as such a committee would be involved in the decision as to whether a xenotransplant clinical trial was performed in the UK. ${ }^{155}$

An exception on the basis of harm being caused for a legitimate reason, such as self defence, can be recognised under the harm principle, ${ }^{156}$ but the preservation of the xenotransplant recipient's life cannot be a legitimate reason to run the risk of causing harm to countless others. Ensuring the health of the greatest number must outweigh the potential benefit of saving one individual life. Given the current pre-clinical evidence on xenotransplantation, an assessment of the possible benefits to the recipient and public health and the risk to public health, must lean towards prohibiting xenotransplantation. Reassurance that such a risk does not exist is not provided by the current scientific evidence. Moreover, once

\footnotetext{
${ }^{152}$ Mill (n 129), at 149.

${ }^{153}$ S Benatar, 'Bioethics: Power and Injustice: IAB Presidential Address' (2003) 17 Bioethics 387; JF Childress, JC Fletcher, 'Respect for Autonomy' (1994) 24 Hastings Center Report 33.

${ }^{154}$ FH Bach, AJ Ivinson, HE Judge Christopher Weeramantry, 'Ethical and Legal Issues in Technology: Xenotransplantation' (2001) 27 American Journal of Law and Medicine 283, 293.

${ }^{155}$ See $D H$ (n 16).

${ }^{156}$ Mill (n 129), at 163.
} 
xenotransplantation clinically proceeds it is impossible to guarantee that public health is not at risk and the danger of disease transfer and a pandemic moves from theoretical to real. And if they actualise it will be too late.

The public interest in health thus offers a powerful reason for state interference to prohibit xenotransplantation. Combining the precautionary principle with the harm principle means that if the actions of medical researchers harm or, crucially, might harm others, then it is legitimate for the State to intervene. This does not mean that prohibition is the only option; rather, the level of the intervention is context specific; regulation and moratoriums are amongst the possibilities. But for xenotransplantation we argue that prohibition is currently most appropriate. Mill argued that there will be cases where state intervention is not justified, despite the fact that an individual's actions have caused harm. ${ }^{157}$ Current available evidence suggests xenotransplantation poses potential for serious harm to public health, so the harm principle should be applied more forcefully to prevent clinical trials proceeding. In the context of xenotransplantation the harm principle thus becomes a liberty limiting rather than liberty enhancing principle. A biotechnology like xenotransplantation requires that the precedence given to an individual interest in health in some societies is challenged, and individual interests take second place to a more communitarian, public health approach.

\section{CONCLUSION}

Xenotransplantation will pose an infection risk to the individual recipient and may unleash unknown and unidentifiable diseases into the population, but an accurate assessment of this risk cannot occur until genetically engineered pig solid organs are xenotransplanted into humans and even then due to the latency of some diseases, such an assessment may be

\footnotetext{
${ }^{157}$ Ibid at 163 .
} 
delayed for many years and hampered by the diagnostic tools currently available. But society has to decide in advance whether the benefit some individuals may obtain from a xenotransplant outweighs the burdens the wider public will have to bear. Making such a decision will not be easy, not only because of this lack of information but also because of difficulties in interpreting the information which does exist. For example, statements that there is no evidence of PERV infection may mean there is no evidence of this so far, but can be interpreted as meaning there is no risk of PERV infection at all. ${ }^{158}$

Given the impossibility of measuring the risks of xenotransplantation and the "histories of lentiviruses and prions have taught us about the untameable distances between the laboratory, the spread of infectious diseases and public health", ${ }^{159}$ a better approach would be to avoid taking the risk to ensure that needless harm is not created. ${ }^{160}$ This may seem unnecessarily precautionary but as there are alternatives to xenotransplantation including reforming existing allotransplant recovery systems and structures and the promise of stem cells, ${ }^{161}$ there is no need to create this risk in the first place. In the light of the limited pre-clinical survival times, uncertainty as to the ability of genetically engineered pig organs to support human life, the potentially catastrophic risks, and the difficulties in identifying, managing and controlling those risks, it is unclear why some still view xenotransplantation as a viable solution to the shortage of organs. ${ }^{162}$ In this environment, the public interest in health and state obligations to protect public health require the state to prohibit clinical xenotransplantation.

\footnotetext{
${ }^{158}$ See D Fisk, 'Perception of Risk - Is the Public Probably Right?', IE Taylor, 'Political Risk Culture: Not Just A Communication Failure' both in P Bennett, K Calman (eds) Risk Communication and Public Health (2001) Oxford University Press.

${ }^{159}$ C Michie, 'Xenotransplantation: Endogenous Pig Retroviruses and the Precautionary Principle' (2001) 7 Trends in Molecular Medicine 62, 63.

${ }^{160}$ For a discussion of such an approach see, for example, Taylor (n 158), at 167.

${ }^{161}$ See, for example, J McHale, M Fox, Health Care Law: Text and Materials (2007) Sweet \& Maxwell, 11621177.

${ }^{162}$ For example, RN Pierson and others, 'Current Status of Xenotransplantation and Prospects for Clinical Application’ (2009) 16 Xenotransplantation 263.
} 